\title{
Computational Approach for Locating Effective Cyanobacterial Compounds against Mycobacterium Tuberculosis
}

\author{
Shasank S. Swain ${ }^{1}$, Sudhir K. Paidesetty ${ }^{2}$, Rabindra N. Padhy ${ }^{1}$ and Pawan K. Singh ${ }^{3}$ \\ ${ }^{1}$ Central Research Laboratory, IMS \& Sum Hospital, Siksha 'O' Anusandhan University, Kalinga Nagar, Bhubaneswar 751003, Odisha, \\ INDIA. \\ ${ }^{2}$ Department of Pharmaceutical Chemistry, School of Pharmaceutical Sciences, Siksha 'O' Anusandhan University, Kalinga Nagar, \\ Bhubaneswar 751003, Odisha, INDIA. \\ ${ }^{3}$ Department of Botany, Banaras Hindu University (BHU), Varanasi 22005, UP, INDIA
}

\begin{abstract}
Introduction: Mycobacterium tuberculosis has been a grievous pathogen causing staggering infections worldwide; especially its recently drug resistant strains are intractable. The MurA ligase of cell-wall peptidoglycan pathway is the suitable target often used for drug development. Methods: A homology model of MurA enzyme of $M$. tuberculosis was generated and validated by a Ramachandran plot for use in molecular docking studies with 13 cyano-compounds, along with 4 first-line anti-tuberculosis drugs, isoniazid, pyrazinamide, ethambutol and rifampicin. Results: Docking scores of two most effective cyano-compounds, pitipeptolides $F$ and pitipeptolides $D$ are -13.765 and $-13.678 \mathrm{kcal} / \mathrm{mol}$, respectively, whereas that of rifampicin is $-9.173 \mathrm{kcal} / \mathrm{mol}$. Computed $\mathrm{LD}_{50}$ values of the majority cyano-compounds were $200 \mathrm{mg} / \mathrm{kg}$ in mouse models, whereas that of isoniazid is $133 \mathrm{mg} / \mathrm{kg}$. Most cyano-compounds, isoniazid and rifampicin are of the class III toxicity level or slightly toxic. Isoniazid has the highest $\mathrm{LC}_{50}$ value around $0.7 \mathrm{mmol}$ against fathead minnow fish, but it is carcinogenic and mutagenic, as known from the computational prediction. Conclusion: Effective-most cyano-compounds, pitipeptolides $\mathrm{F}$ and pitipeptolides $D$ could be used as alterative/ complementary agents against recently reported drug-resistant strains of $M$. tuberculosis.
\end{abstract}

Key words: Tuberculosis, MurA enzyme, Cyano-compounds, Antimycobacterial inhibitors, Computational toxicity study, Molecular docking.

\section{INTRODUCTION}

A survey of World Health Organization (WHO) reveals that 9.2 million new tubercle bacillus (TB) or Mycobacterium tuberculosis (Mtb) infection cases are recorded globally, of which about 3 million infections from Africa, a 3 million from Southeast Asia and about a 2 million from Western Pacific region are reported. Furthermore, India and China are reported to have the largest total numbers of new cases, while South Africa had the highest rate of new cases. ${ }^{1,2}$ Despite the use of the combination-chemotherapy with 4 first-line drugs, isoniazid, pyrazinamide, ethambutol and rifampicin, along with selective second-line drugs in the regular therapy and in the 'directly observed treatment shortcourse programme', mortality figure is consistently increasing in African and South Asian countries. ${ }^{3}$ Furthermore, several second-line drugs, chemotherapeutics (ethionamide, thiacetazone, prothionamide and clofazimine), antibiotics (amikacin, kanamycin, debekacin, cycloserine, capreomycin and viomycin) are not well tolerated. ${ }^{3}$ Moreover, multidrug resistant (MDR), resistance to at least isoniazid and rifampicin, extensively drug-resistant (XDR) and extremely drug-resistant (XXDR)
Submission Date: 30-08-2016; Revision Date: 17-11-2016; Accepted Date: 23-11-2016

DOI: 10.5530/ijper.51.2.36 Correspondence: Rabindra N. Padhy, Central Research Laboratory, IMS \& Sum Hospital, Siksha 'O' Anusandhan University, Kalinga Nagar, Bhubaneswar 751003, Odisha, INDIA.

E-mail: rnpadhy54@gmail. com

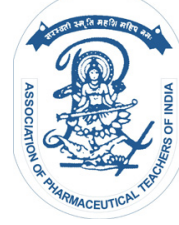

www.ijper.org 
and ghoulish totally drug-resistant (TDR) tuberculosis cases described as resistant to resistant 'all first-line drugs and second-line drugs' TB strains have emerged, rendering the present module of chemotherapy ineffective at several areas..$^{4-6}$ Mainly, Mtb developed resistance to pyrazinamide with alteration(s) in cell wall synthesis. ${ }^{7,8}$ In this scenario, the development of a novel well-tolerated and emulating anti-mycobacterial agent, for the control of MDR, XDR or TDR Mtb, is a dire necessity.

Peptidoglycan layer is the major component of $\mathrm{Mtb}$ bacterial cell wall providing shape and rigidity, as in eubacteria. It is a homogeneous polymer consisting of sugar and amino acid polymers, $\mathrm{N}$-acetylglucosamine (GlcNAc) and N-acetylmuramic acid (MurNAc), crosslinked by trans-peptide bridges, lying exterior to the plasma membrane. The biosynthesis of peptidoglycan layer is catalysed by enzymes, GlmS, GlmM, GlmU, MurA, MurB, MurC, MurD, MurE and MurF, at several coordinated cytoplasmic and periplasmicsteps (Table 1). ${ }^{9,10}$ In the cytoplasmic step, the synthesis of UDP-MurNAc from UDP-GlcNAc is mediated by MurA ligase (UDP$\mathrm{N}$-acetylglucosamine 1-carboxyvinyl transferase), which was used as a suitable target for the drug development attempt. ${ }^{9-12}$ Previously for drug development, to address drug resistant strains of the Gram-positive bacterium, Enterococcus faecalis as well as, of M. leprae, Mur ligases were shown as target enzymes in molecular docking attempts. ${ }^{13,14}$ Obviously, an in silico computation would help locating a suitable control agent without the hit-andmiss method, which is often followed in drug targeting attempts; in vivo attempts would follow by apothecary, after being suitably indicated by computational work. Since, no molecular docking work using any Mur ligase is reported for drug targeting Mtb, this work describes screening of 13 cyano-compounds as possible antimycobacterial agents. As it is, cyanobacteria constitute a unique group of photosynthetic prokaryotes growing in soil, inland and marine waters. Several bioactive cyanocompounds have been isolated and characterized, which could be used in drug discovery, for example, against cancer. ${ }^{15}$ Here only 13 cyano-compounds were selected in docking attempts against Mtb MurA enzyme from earlier reports on antimycobacterial activity. ${ }^{16-18}$

Nuclear magnetic resonance (NMR) or X-ray crystallography structure of Mtb MurA enzyme is not yet reported and that being unavailable in Protein Data Bank (PDB), in this work a homology model of Mtb MurA is generated and validated by a Ramachandran plot. It was further used as the drug-target in docking study with cyano-compounds, in comparison to 4 firstline anti-tuberculosis drugs and antibiotic, isoniazid, pyrazinamide, ethambutol and rifampicin, individually. Toxicity study is an essential corollary, before the pre-clinical stage of a recommended chemical, which is predicted suitable as drugable agent computationally. It is anticipated that the most effective cyano-compound determined herein could be used as new anti-tuberculosis drug.

\section{MATERIALS AND METHODS}

\section{Homology modeling of $M$. tuberculosis MurA ligase}

The amino acid sequence of Mtb MurA ligase was retrieved from the UniProtKB database (http://www. uniprot.org/). The 3-Dstructure of MurA ligase was modelled using the MurA of the bacterium, Listeria monocytogenes as the suitable template, with the help of tools, BLASTp (http://blast.ncbi.nlm.nih.gov/Blast), Phyre2 (http://www.sbg.bio.ic.ac.uk/phyre2), CS-BLAST (http://toolkit.tuebingen.mpg.de/cs_blast), I-TASSER (http://zhanglab.ccmb.med.umich.edu/I-TASSER/)

\begin{tabular}{|} 
Table 1: Family of muramidase (Mur) ligases involved in peptidoglycan synthesis of \\
Mycobacterium tuberculosis.
\end{tabular}

EC no., Enzyme commission number 
and RaptorX (http://raptorx.uchicago.edu/).The secondary structure and protein sequence analyses of Mtb MurA were predicted by tools, PSIPRED (http:// bioinf.cs.ucl.ac.uk/psipred/), SOPMA tool (http:// nhjy.hzau.edu.cn/) and ProtParam (http://web.expasy. org/protparam/).

\section{Model validation}

The homology model of Mtb MurA ligase was generated by the MODELLER 9.14 software (academic version; http//:www.salilab.org/modeler. ${ }^{19}$ Based on the lowest value of normalized discrete optimized protein energy (DOPE) of 5 generated homology models, the suitable 3-D model was selected and validated using the tool, Structure Analysis and Verification Server (SAVES) (http://services.mbi.ucla.edu/) with programmes, PROCHECK, VERIFY3D, ERRAT and PROVE, to verify bond length values, dihedral and torsion angles attained a stable configuration, by generating a Ramachandran plot. Moreover, Ramachandran plot analysis (http://mordred.bioc.cam.ac.uk/), WHAT IF (http://swift.cmbi.ru.nl/), MolProbity (http:// molprobity.biochem.duke.edu/) and ProSA-web (https://prosa.services.came.sbg.ac.at/) were too used for checking the reliability of the generated homology model of MurA ligase. Furthermore, the model was subjected to energy minimization by the Swiss-Pdb Viewer (http://spdbv.vital-it.ch/) software, for maintaining its stability before a docking attempt.

\section{Molecular docking}

In molecular docking, the possibility of blocking the target protein/receptor, involved in a particular disease by a ligand in inhibiting its active site(s), is assessed. A ligand gets attached onto the larger molecule, the receptor in a specific orientation with generation of an energy value, the docking score ( $\mathrm{kcal} / \mathrm{mol}$.), specific for the particular protein-ligand complex. The most effective ligand is selected from the minimum docking score of a complex, among several ligands and similar receptor complexes.

Structures of 13 cyano-compounds and 4 on-going anti-tuberculosis drugs were retrieved from the chemical database, PubChem (https://pubchem.ncbi.nlm.nih. gov/search/ search.cgi) and the DrugBank (http:// www.drugbank.ca/), respectively, for docking study. The retrieved structures of compounds/ drugs were saved into dot mol or '.mol' and dot pdb or '.pdb' file formats for use in molecular docking, which were done by using AutoDock Vina and PatchDock softwares, as reported. ${ }^{20,21}$ Docking studies with receptor enzyme MurA and individual ligands as cyano-compounds and 4 first-line anti-tuberculosis drugs were attempted. PyMOL (https://www.pymol.org/) and LigPlot (http://www.ebi.ac.uk/thornton-srv/software/ LIGPLOT/\#) softwares were used to visualize the generated 3-D model of MurA ligase and its interactions with ligands in docking study.

\section{In silico toxicity prediction}

The in silico toxicity prediction remains an advanced approach to rationalize the process of preclinical drug development, by reducing the associated time and costs on animal experiments. Here, the ProTox (http://tox. charite.de/tox) web server was used in evaluating $\mathrm{LD}_{50}$ values of oral toxicity and the toxicity class of the used cyano-compounds. Additionally, the chemoinformatic tool LAZAR (Lazy Structure-Activity Relationships) (http:/ / lazar.in-silico.de/predict) was used for assessing carcinogenic and mutagenic natures, along with assessing possible $\mathrm{LC}_{50}$ value and the daily recommended dose of each cyano-compound used herein and anti-tuberculosis drugs. LAZAR provides $85 \%$ mutagenicity and carcinogenicity up to $95 \%$ predictions for a query compound. Moreover, recommended daily dose of a query compound, herein a cyano-compound is calculated by comparison with data of available training set or known drugs approved by Food and drug administration.

\section{RESULTS}

\section{Homology modeling of M. tuberculosis MurA ligase}

After retrieval of target sequence of Mtb MurA ligase, 6 bioinformatics tools were used to find out the suitable template for modeling a 3-D structure. Based on the higher level of sequence similarity and identity, the structure of L. monocytogenes MurA ligase was selected as the suitable template with $48 \%$ identity long with query coverage at $99 \%$ for the homology modeling. The template modeling or TM score of MurA was 0.97 obtained through the TM-align programme of I-TASSER. The TM score was seen lying between 0.0 and 1.0 (and is $>0.5$ ), which signifies that the MurA structure and selected template were in the same fold. The secondary structure of MurA ligase was predicted as $38.52 \%$ helix, $19.62 \%$ extended strand, $9.57 \%$ beta-turn and $32.30 \%$ random coil, by the SOPMA tool, which supported the stability of the protein due to the presence of indicated high percentage of helix. The generated homology model as 3-D structure of MurA ligaseof $M$. tuberculosis with helix, sheet and loop regions in three different colors is presented by PyMOL software (Figure 1).The predicted molecular weight of MurA is $44063.5 \mathrm{kd}$, theoretical isoelectric point is 


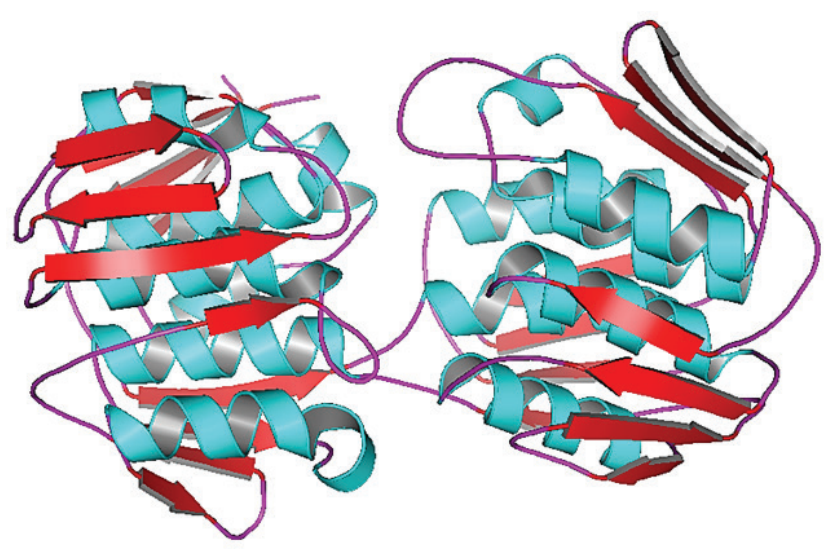

Figure 1: Generated homology model as 3-D structure of MurA ligaseof $\boldsymbol{M}$. tuberculosis by PyMOL visualizer software. In this structure, sky blue color stretches are helix regions, red stretches indicate sheets and violet pink stretches indicate loops.

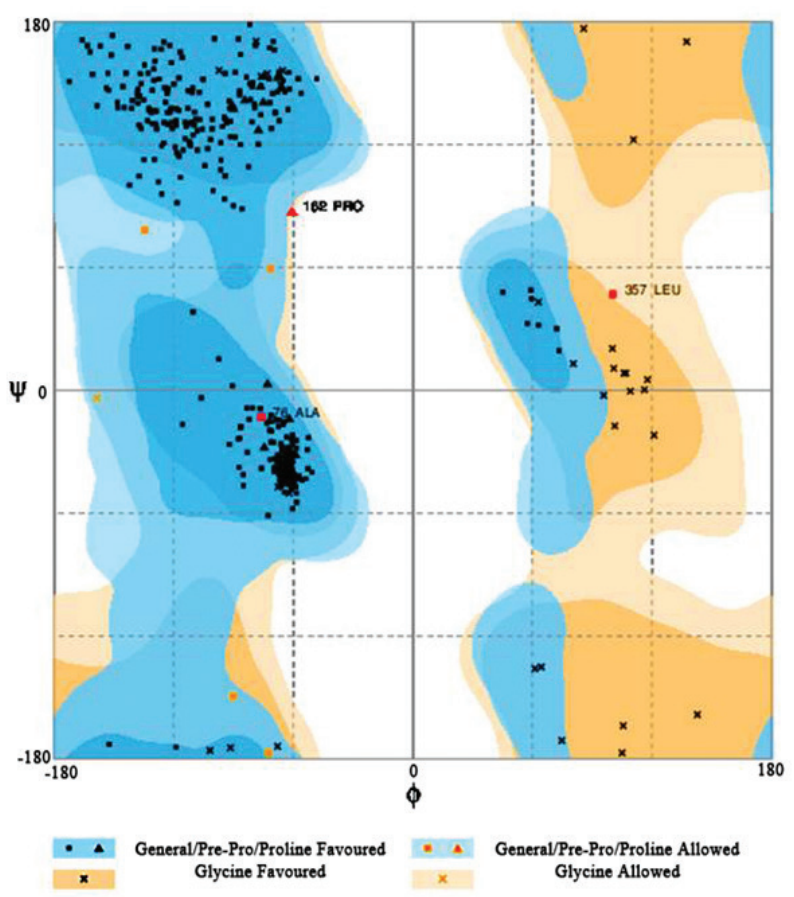

Figure 2: Ramachandran plot statistics of the generated model of Mtb MurA enzyme. The plot was calculated with the Ramachandran plot analysis program, where $98.1 \%$ amino acids are in favoured region $1.2 \%$ amino acids are in allowed region and $0.7 \%$ amino acids are in outlier region.

5.30 and the instability index is $28.49(<40)$. As a result, instability index value and a higher proportion of the peptide as helix indicated that the protein is more stable in nature, determined by the ProtParam tool. In total numbers of negative charged residues are $49 \%$ and the positive charged residues are $34 \%$, which indicated the MurA enzyme as acidic in nature.

\section{Model validation}

The Ramachandran plot statistics indicated that, $98.1 \%$ residues were in the most favored region, $1.2 \%$ residues were in allowed region and only $0.7 \%$ residues were in the disallowed region (Figure 2). Thus, the generated model of MurA was geometrically and stereo-chemically acceptable. Further, knowledge-based energy curves were generated for the target with Z-score values (MurA Z-score: -9.95), and for the template (3R38 Z-score: -10.92) by using ProSA-web (Supplementary Figure 1). The Z-score and energy curve also indicated that the MurA model was within the Z-score range of experimentally determined NMR solved protein structure; and the Z-score of template was less different to the modeled MurA structure; ProSA-web confirmed the quality and consistency of the model that is acceptable. Data regarding the validation of the generated MurA model was validated.

\section{Molecular docking}

Thirteen cyano-compounds and 4 anti-tuberculosis drugs were docked individually against generated target, the Mtb MurA enzyme. Effective docking score values of 4 anti-tuberculosis drugs are as given against each (kcal/mol), -9.173 (rifampicin) > -7.865 (ethambutol) $>-7.568$ (isoniazid) $>-6.981$ (pyrazinamide) (Table 2). Among cyano-compounds, pitipeptolides F with docking score value, -13.765 was the most effective cyano-compound against Mtb MurA enzyme. Effective docking score values of 13 cyano-compounds are as given against each (kcal/mol): -13.765 (pitipeptolides F)
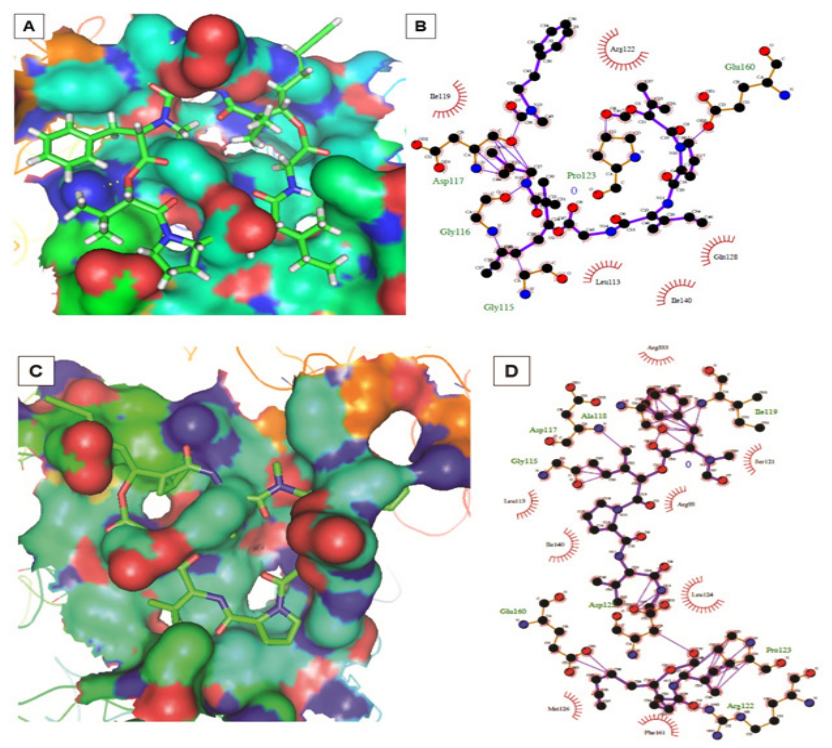

Figure 3: Interaction of the target Mtb MurA ligase with two effective cyano-compounds in docking attempts, visualized by softwares PyMOL and LigPlot. A and B represent two surface interaction-views of pitipeptolides $D$. And $C$ and $D$ represent surface interaction-views of MurA ligase with pitipeptolides $F$. 


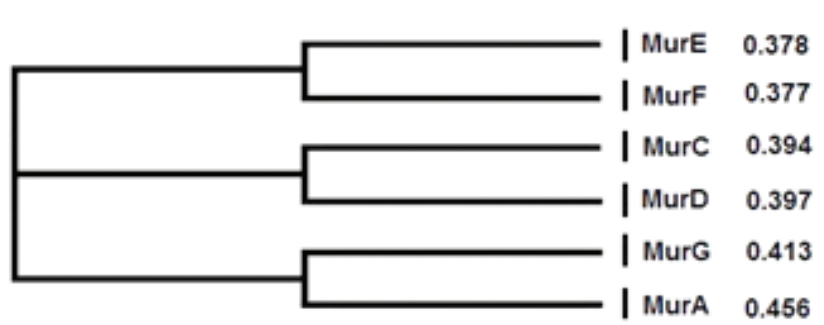

Figure 4: Phylogenetic tree of MurA, MurC, MurD, MurE, MurF and MurG of $M$. tuberculosis ATCC 25618/H37Rv.

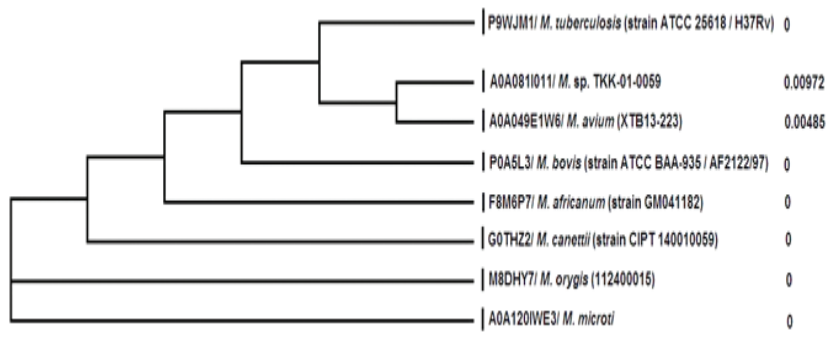

Figure 5: Phylogenetic tree was constructed using MurA enzyme of 8 species of Mycobacterium.

\begin{tabular}{|c|c|c|c|c|}
\hline $\begin{array}{l}\text { Cyano-compound; chemical } \\
\text { class }\end{array}$ & $\begin{array}{l}\text { Source organisms; } \\
\text { Reference }\end{array}$ & 3-D structure & Information & $\begin{array}{l}\text { Docking } \\
\text { score }\end{array}$ \\
\hline $\begin{array}{l}\text { Ambiguine } \mathrm{A} \text { isonitrile; } \\
\text { indole alkaloid }\end{array}$ & Fischerella ambigua; ${ }^{22}$ & & $\begin{array}{l}\text { Compound ID: } 21610112 \\
\text { MW:406.99074g/mol } \\
\text { MF: } \mathrm{C}_{26} \mathrm{H}_{31} \mathrm{CIN}_{2} \\
\text { H-bd:1 } \\
\text { H-ba: } 1\end{array}$ & -9.193 \\
\hline $\begin{array}{l}\text { Ambiguine } \mathrm{K} \text { isonitrile; } \\
\text { indole alkaloid }\end{array}$ & Fischerella ambigua; ${ }^{16}$ & & $\begin{array}{l}\text { Compound ID: } 44139368 \\
\text { MW: } 420.97426 \mathrm{~g} / \mathrm{mol} \\
\text { MF: } \mathrm{C}_{26} \mathrm{H}_{29} \mathrm{CIN}_{2} \mathrm{O} \\
\mathrm{H}-\mathrm{bd}: 2 \\
\mathrm{H}-\mathrm{ba}: 2\end{array}$ & -9.079 \\
\hline $\begin{array}{l}\text { Ambiguine } \mathrm{M} \text { isonitrile; } \\
\text { indole alkaloid }\end{array}$ & Fischerella ambigua; ${ }^{16}$ & & 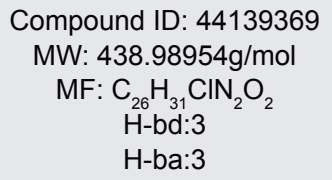 & -9.377 \\
\hline $\begin{array}{c}\text { Eucapsitrione; anthraquinone } \\
\text { derivative }\end{array}$ & $\begin{array}{c}\text { Eucapsis sp. and Fischerella } \\
\text { ambigua; }{ }^{17}\end{array}$ & & $\begin{array}{l}\text { Compound ID: } 46919489 \\
\text { MW: } 358.3005 \mathrm{~g} / \mathrm{mol} \\
\text { MF: } \mathrm{C}_{21} \mathrm{H}_{10} \mathrm{O}_{6} \\
\mathrm{H}-\mathrm{bd}: 3 \\
\mathrm{H}-\mathrm{ba}: 6\end{array}$ & -10.361 \\
\hline $\begin{array}{l}\text { Fischambiguine } \mathrm{B} \text {; } \\
\text { indole alkaloid }\end{array}$ & Fischerella ambigua; ${ }^{22}$ & & $\begin{array}{l}\text { Compound ID: } 71452317 \\
\text { MW: } 436.97366 \mathrm{~g} / \mathrm{mol} \\
\text { MF: } \mathrm{C}_{26} \mathrm{H}_{29} \mathrm{CIN}_{2} \mathrm{O}_{2} \\
\text { H-bd: } 2 \\
\text { H-ba: } 3\end{array}$ & -9.625 \\
\hline $\begin{array}{l}\text { Hapalindole A; } \\
\text { alkaloid; }\end{array}$ & $\begin{array}{l}\text { Hapalosiphon fontinalis and } \\
\text { Fischerella sp.; }{ }^{23}\end{array}$ & & $\begin{array}{l}\text { PubChem ID:185159 } \\
\text { MF: } \mathrm{C}_{21} \mathrm{H}_{23} \mathrm{CIN}_{2} \\
\text { MW:338.87372 [g/mol] } \\
\text { H-bd:1 } \\
\text { H-ba:1 }\end{array}$ & -9.891 \\
\hline $\begin{array}{l}\text { Pitipeptolides A; } \\
\text { cyclic depsipeptide }\end{array}$ & Lyngbya majuscula; ${ }^{24}$ & & $\begin{array}{l}\text { Compound ID: } 11803484 \\
\begin{array}{c}\text { MW: } 808.015[\mathrm{~g} / \mathrm{mol}] \\
\text { MF: } \mathrm{C}_{44} \mathrm{H}_{65} \mathrm{~N}_{5} \mathrm{O}_{9} \\
\mathrm{H}-\text { bd: } 3 \\
\text { H-ba: } 9\end{array}\end{array}$ & -12.672 \\
\hline $\begin{array}{l}\text { Pitipeptolides B; cyclic } \\
\text { depsipeptide }\end{array}$ & Lyngbya majuscule; ${ }^{24}$ & & $\begin{array}{l}\text { Compound ID: } 10819182 \\
\text { MW: } 810.03088[\mathrm{~g} / \mathrm{mol}] \\
\text { MF: } \mathrm{C}_{44} \mathrm{H}_{67} \mathrm{~N}_{5} \mathrm{O}_{9} \\
\text { H-bd: } 3 \\
\text { H-ba: } 9\end{array}$ & -12.175 \\
\hline
\end{tabular}

Continued... 


\begin{tabular}{|c|c|c|c|c|}
\hline $\begin{array}{l}\text { Pitipeptolides C; cyclic } \\
\text { depsipeptide }\end{array}$ & $\begin{array}{l}\text { Lyngbya } \\
\text { majuscule; }{ }^{18}\end{array}$ & 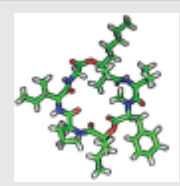 & $\begin{array}{l}\text { Compound ID: } 15479259 \\
\text { MW: } 812.04676[\mathrm{~g} / \mathrm{mol}] \\
\begin{array}{c}\text { MF: } \mathrm{C}_{44} \mathrm{H}_{69} \mathrm{~N}_{5} \mathrm{O}_{9} \\
\text { H-bd: } 3 \\
\text { H-ba: } 9\end{array}\end{array}$ & -12.988 \\
\hline $\begin{array}{l}\text { Pitipeptolides D; cyclic } \\
\text { depsipeptide }\end{array}$ & Lyngbya majuscule; ${ }^{18}$ & & 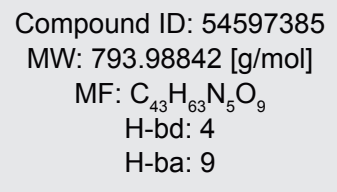 & -13.678 \\
\hline $\begin{array}{l}\text { Pitipeptolides E; cyclic } \\
\text { depsipeptide }\end{array}$ & Lyngbya majuscule; ${ }^{18}$ & & $\begin{array}{l}\text { Compound ID: } 54597438 \\
\text { MW: } 793.98842[\mathrm{~g} / \mathrm{mol}] \\
\begin{array}{c}\text { MF: } \mathrm{C}_{43} \mathrm{H}_{63} \mathrm{~N}_{5} \mathrm{O}_{9} \\
\text { H-bd: } 3 \\
\text { H-ba: } 9\end{array}\end{array}$ & -13.152 \\
\hline $\begin{array}{l}\text { Pitipeptolides F; cyclic } \\
\text { depsipeptide }\end{array}$ & Lyngbya majuscule; ${ }^{18}$ & & 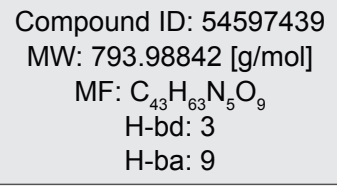 & -13.765 \\
\hline $\begin{array}{l}\text { Scytoscalarol; } \\
\text { terterpene }\end{array}$ & Scytonema sp.; ${ }^{22}$ & & $\begin{array}{l}\text { Compound ID: } 49775750 \\
\begin{aligned} \text { MW: } 415.655[\mathrm{~g} / \mathrm{mol}] \\
\text { MF: } \mathrm{C}_{26} \mathrm{H}_{45} \mathrm{~N}_{3} \mathrm{O} \\
\mathrm{H}-\text { bd: } 3 \\
\text { H-ba: } 2\end{aligned}\end{array}$ & -11.710 \\
\hline Ethambutol* $^{*}$ & - & & $\begin{array}{c}\text { DrugBank ID: DB00330 } \\
\text { MW: } 204.30976[\mathrm{~g} / \mathrm{mol}] \\
\text { MF: } \mathrm{C}_{10} \mathrm{H}_{24} \mathrm{~N}_{2} \mathrm{O}_{2} \\
\text { H-bd:4 } \\
\text { H-ba: } 4\end{array}$ & -7.065 \\
\hline Isoniazid* & - & & $\begin{array}{c}\text { DrugBank ID: DB00951 } \\
\text { MW: } 137.13928[\mathrm{~g} / \mathrm{mol}] \\
\text { MF: } \mathrm{C}_{6} \mathrm{H}_{7} \mathrm{~N}_{3} \mathrm{O} \\
\mathrm{H}-\text { bd: } 2 \\
\text { H-ba: } 3\end{array}$ & -7.568 \\
\hline Pyrazinamide* & - & & $\begin{array}{c}\text { DrugBank ID: DB00339 } \\
\text { MW: } 123.1127[\mathrm{~g} / \mathrm{mol}] \\
\text { MF: } \mathrm{C}_{5} \mathrm{H}_{5} \mathrm{~N}_{3} \mathrm{O} \\
\mathrm{H}-\text { bd: } 1 \\
\text { H-ba: } 3\end{array}$ & -6.981 \\
\hline Rifampicin* & - & & $\begin{array}{c}\text { DrugBank ID: DB01045 } \\
\text { MW: } 822.94022[\mathrm{~g} / \mathrm{mol}] \\
\text { MF: } \mathrm{C}_{43} \mathrm{H}_{58} \mathrm{~N}_{4} \mathrm{O}_{12} \\
\text { H-bd: } 6 \\
\text { H-ba: } 15\end{array}$ & -9.173 \\
\hline
\end{tabular}

*, antibiotics, $\mathrm{H}$-ba, hydrogen-bond acceptor; $\mathrm{H}$-bd, hydrogen-bond donor; MF, molecular formula; MW, molecular weight.

$>-13.678$ (pitipeptolides D) $>-13.152$ (pitipeptolides E)

$>-12.988$ (pitipeptolides C) $>-12.672$ (pitipeptolides A)

$>-12.175$ (pitipeptolides B) $>-11.710$ (scytoscalarol)

$>-10.361$ (eucapsitrione) $>-9.891$ (hapalindole A)

$>-9.625$ (fischambiguine $\mathrm{B}$ ) $>-9.377$ (ambiguine $\mathrm{M}$ isonitrile) $>-9.193$ (ambiguine $\mathrm{A}$ isonitrile) $>-9.079$ (ambiguine $\mathrm{K}$ isonitrile) (Table 3). Moreover, all used cyano-compounds had the higher docking score values in comparison to those of TB-drugs used. Interactions of cyano-compounds, pitipeptolides $\mathrm{F}$ and pitipep- tolides $\mathrm{D}$ with Mtb MurA during docking are elucidated (Figure 3).

\section{In silico toxicity prediction}

According to ProTox web server, the decreasing order of $\mathrm{LD}_{50}$ values $(\mathrm{mg} / \mathrm{kg})$ are cited against each compound: rifampicin (3222), pyrazinamide (1800), scytoscalarol (1600), ethambutol (998), eucapsitrione (385), six pitipeptolides A, B, C, D, E, F (200, each), isoniazid (133), ambiguine $\mathrm{M}$ isonitrile (136), and fischambiguine $\mathrm{B}$ (136), ambiguine $\mathrm{A}$ isonitrile (110) and hapalindole $\mathrm{A}$ 


\section{Table 3: In silico toxicity assessment of cyano-compounds along with those of anti-TB drugs as references,} with maximum FDA recommended daily dose (mmol).

\begin{tabular}{|c|c|c|c|c|}
\hline $\begin{array}{l}\text { Cyano-compound/ } \\
\text { Anti-TB drug }\end{array}$ & Fish toxicity $L_{50}$ & $\begin{array}{c}\text { Mouse } \\
\text { carcinogenicity; } \\
\text { mutagenicity }\end{array}$ & $\begin{array}{l}\mathrm{LD}_{50} \\
\text { toxicity } \\
\text { class }\end{array}$ & Recommended daily dose \\
\hline Ambiguine $\mathrm{A}$ isonitrile & 0.0034082947466186 & $\begin{array}{l}\text { Non-carcinogen; } \\
\text { non-mutagenic }\end{array}$ & 110; III & 0.00174816485794716 \\
\hline Ambiguine $\mathrm{K}$ isonitrile & 0.00154367939121187 & $\begin{array}{l}\text { Non-carcinogen; } \\
\text { non-mutagenic }\end{array}$ & 60 ; III & 0.00227899315840001 \\
\hline Ambiguine $\mathrm{M}$ isonitrile & 0.00738241180993074 & $\begin{array}{l}\text { Non-carcinogen; } \\
\text { non-mutagenic }\end{array}$ & 136; III & 0.00594116677457886 \\
\hline Eucapsitrione & Not predicted & $\begin{array}{l}\text { Non-carcinogen; } \\
\text { mutagenic }\end{array}$ & 385; IV & Not predicted \\
\hline Fischambiguine B & 0.00699000000000007 & $\begin{array}{l}\text { Non-carcinogen; } \\
\text { non-mutagenic }\end{array}$ & 136; III & 0.00591692988293637 \\
\hline Hapalindole A & 0.00248004404055083 & $\begin{array}{l}\text { Non-carcinogen; } \\
\text { non-mutagenic }\end{array}$ & 110; III & 0.00178878082978523 \\
\hline Pitipeptolides A & 0.0231924977492949 & $\begin{array}{l}\text { Non-carcinogen; } \\
\text { non-mutagenic }\end{array}$ & 200; III & 0.00236752726254867 \\
\hline Pitipeptolides B & 0.0183395882632407 & $\begin{array}{l}\text { Non-carcinogen; } \\
\text { non-mutagenic }\end{array}$ & 200; III & 0.00236752726254867 \\
\hline Pitipeptolides C & 0.0242958427200449 & $\begin{array}{l}\text { Non-carcinogen; } \\
\text { non-mutagenic }\end{array}$ & 200; III & 0.00196920696078117 \\
\hline Pitipeptolides D & 0.0163871000518421 & $\begin{array}{l}\text { Non-carcinogen; } \\
\text { non-mutagenic }\end{array}$ & 200; III & 0.00211958401295321 \\
\hline Pitipeptolides E & 0.0231924977492949 & $\begin{array}{l}\text { Non-carcinogen; } \\
\text { non-mutagenic }\end{array}$ & 200; III & 0.00174822126733245 \\
\hline Pitipeptolides F & 0.020663724682756 & $\begin{array}{l}\text { Non-carcinogen; } \\
\text { non-mutagenic }\end{array}$ & 200; III & 0.00224508680995582 \\
\hline Scytoscalarol & Not predicted & $\begin{array}{c}\text { Carcinogen; } \\
\text { non-mutagenic }\end{array}$ & 1600; IV & 0.00811053697038394 \\
\hline Ethambutol & Not predicted & $\begin{array}{l}\text { Non-carcinogen; } \\
\text { non-mutagenic }\end{array}$ & 998; IV & 0.0490197349457053 \\
\hline Isoniazid & 0.700645136095585 & Carcinogen; mutagenic & 133; III & -1.1371618461445 \\
\hline Pyrazinamide & Not predicted & $\begin{array}{l}\text { Non-carcinogen; } \\
\text { non-mutagenic }\end{array}$ & 1800; IV & -0.613181576657421 \\
\hline Rifampicin & 0.00552411213689556 & $\begin{array}{l}\text { Non-carcinogen; } \\
\text { Not predicted }\end{array}$ & $3322 ; \mathrm{V}$ & 0.012826812250905 \\
\hline
\end{tabular}

Note: FDA, Food and drug administration; Toxicity (mg/kg) class I: fatal if swallowed, LD 505 ; and likewise, class II, fatal: $5 \leq 50 ;$ class III, toxic: $50 \leq 300$; class IV, harmful: $300 \leq 2000$; class V, may be harmful: $2000 \leq 5000$; and class VI, non-toxic: > 5000 .

(110) and ambiguine A isonitrile (60) (Table 3; Suppl. Fig. 2). Among cyano-compounds and 4 anti-TB drugs, ambiguine $\mathrm{A}$ isonitrile, ambiguine $\mathrm{K}$ isonitrile, ambiguine $\mathrm{M}$ isonitrile, fischambiguine $\mathrm{B}$, hapalindole A, pitipeptolides A, pitipeptolides B, pitipeptolides C, pitipeptolides D, pitipeptolides E, pitipeptolides F and isoniazid are in class III of toxicity compounds $\left(\mathrm{LD}_{50}\right.$ value with $50 \leq 300 \mathrm{mg} / \mathrm{kg}$, and increase in the toxicity class is marked by decreased toxic effects); and eucapsitrione, scytoscalarol, ethambutol and pyrazinamide are in class IV of toxicity compounds $\left(\mathrm{LD}_{50}\right.$ would be $300 \leq 2000 \mathrm{mg} / \mathrm{kg}$ in this class); and only rifampicin is in class $\mathrm{V}$ toxicity compound $\left(\mathrm{LD}_{50}\right.$ would be $2000 \leq$ $5000 \mathrm{mg} / \mathrm{kg}$ in this class) (Table 3). Moreover, isoniazid and 11 cyano-compounds would be in class III toxic compound, but none of the later is carcinogenic. Thus, in comparison to isoniazid, $\mathrm{LD}_{50}$ values of most cyano-compounds are less toxic; and thus those could be promoted as drugs due to lesser levels of toxicity (Table 3). According to LAZAR tool, used13 cyanocompounds and the rest of the 3 anti-tuberculosis drugs are arranged according to fish toxicity (in decreasing order of $\mathrm{LC}_{50}$ value): pitipeptolides $\mathrm{C}$, pitipeptolides $\mathrm{A}$, pitipeptolides E, pitipeptolides $\mathrm{F}$, pitipeptolides $\mathrm{B}$, pitipeptolides $\mathrm{D}$,ambiguine $\mathrm{M}$ isonitrile, fischambiguine $\mathrm{B}$, rifampicin, ambiguine $\mathrm{A}$ isonitrile, hapalindole $\mathrm{A}$, and ambiguine K isonitrile (Table 3, Supplementary Figure 3). And the rest 4 compounds, eucapsitrione, scytoscalarol, 
ethambutol and pyrazinamide were not predicted any bio-toxicity by the toxicity analyzer tool, LAZAR. Among 13 cyano-compounds, eucapsitrione is mutagenic and scytoscalarol is carcinogenic in nature. Here, isoniazid has the highest $\mathrm{LC}_{50}$ value around $0.7 \mathrm{mmol}$ against fathead minnow fish in comparison to other anti-TB drugs and the used cyano-compounds, but it has carcinogenic and mutagenic activity as indicated by the computational prediction (Table 3). Moreover, cited cyano-compounds could be promoted as new anti-TB agents based on findings of molecular docking, $\mathrm{LD}_{50}$, $\mathrm{LC}_{50}$ and toxicity class level.

\section{DISCUSSION}

Using computational tools, effective-most cyanocompounds, pitipeptolides $\mathrm{F}$ and pitipeptolides $\mathrm{D}$ were selected and used as alterative/ complementary agents against recently reported drug-resistant strains of $M$. tuberculosis. Computation biology is a system of advanced tools by which, a putative drug target is identified, rather predicted against the 3-D structure of a key target protein of a disease, which may be even generated by homology modeling, as here done for Mtb MurA, using the $L$. monocytogenes MurA structure as the template. Indeed in molecular docking, the target enzyme is blocked by the ligand that would be the probable future drug. Indeed, cyano-compounds from the archaic bacterial group are known to be unique compounds with several therapeutic activities - antibacterial, ${ }^{16,25}$ antifungal ${ }^{26,27}$ and anticancer efficacies. ${ }^{15,28}$ This work computationally describes that two cyanocompounds, pitipeptolides $\mathrm{F}$ and $\mathrm{D}$ as the most effective antimycobacterial agents, in comparison to the presently used individual first-line anti-TB drugs. The in silico attempt of prediction of bio-activity of cyanocompounds included toxicity predictions with fish and mouse models herein. Moreover, isoniazid has been experimentally proved as carcinogenic in vivo mouse model too, ${ }^{29}$ corroborating the in silico prediction presented here.

During a drug development cascade for a disease, screening of a large number of characterized lead compounds are done in pharmacology and medicinal chemistry. But a compound to be designated as drug has to pass through the first stage of pre-clinical trial to four subsequent stages of clinical trials. As it is known, drug candidates entering clinical trials have been estimated having an $8 \%$ chance of becoming marketed drugs with about a $20 \%$ chance of failure due to high levels of host toxicity. ${ }^{30}$ Blithely, modern computational predictions on drugable compounds have advantages in the drug development cascades, of saving the time in the in vitro and tiresome in vivo experiments, which are mandatory for the computationally recommended specific chemical intended as a future drug; nevertheless, animal trials are the essential corollary work in drug development.

\section{CONCLUSION}

The putative drug target, MurA enzyme of Mtb was generated by homology modeling and Ramachandran plot statistics proved that the generated MurA model was geometrically and stereo chemically acceptable. Molecular docking attempts could help locating comparatively more effective agents against the target enzyme MurA than the presently used first-line drugs and antibiotics in TB-chemotherapy. Indeed, cyanobacteria possess unique secondary metabolites with antimycobacterial potency evaluated by docking studies, and the indicated compounds are less toxic than isoniazid. Both molecular docking and toxicity studies indicated that two cyano-compounds, pitipeptolides F and D could be promoted as the effective agents against M. tuberculosis.

\section{ACKNOWLEDGEMENTS}

SS Swain is supported by Siksha ' $O$ ' Anusandhan University, Bhubaneswar, Odisha for $\mathrm{PhD}$ in Biotechnology.

\section{Conflict of Interest}

The authors have declared no conflict of interest.

\section{ABBREVIATION USED}

DOPE: discrete optimized protein energy; LAZAR: Lazy Structure-Activity Relationships; MDR: multidrug resistant; Mtb: Mycobacterium tuberculosis; NMR: nuclear magnetic resonance; SAVES: structure analysis and verification server; TB: tubercle bacillus; TDR: Totally drug-resistant; WHO: World Health Organization; XDR: extensively drug-resistant; XXDR: extremely drug-resistant.

\section{REFERENCES}

1. Anonymous 2013. Global Health Observatory (GHO) data 2013. How many TB cases and deaths are there? (http://www.who.int/gho/tb/epidemic/cases_ deaths/en/).

2. World Health Organization. Global Tuberculosis Report 2014

3. Singh J, Sankar MM, Kumar P, Couvin D, Rastogi N, Singh S, Indian TB Diagnostics Network. Genetic diversity and drug susceptibility profile of Mycobacterium tuberculosis isolated from different regions of India. 
J Infect. 2015;71(2):207-19. https://doi.org/10.1016/j.jinf.2015.04.028 PMid:25934327.

4. Dubey D, Rath S, Sahu MC, Nayak N, Debata NK, Padhy RN. Status of multidrug resistance in tubercle bacillus and phyto-chemicals for the control. $J$ Publ Health. 2013;21(1):115-19. https://doi.org/10.1007/s10389-012-0514-y.

5. Migliori GB, Centis R, D'Ambrosio L, Spanevello A, Borroni E, Cirillo DM, Sotgiu G. Totally drug-resistant and extremely drug-resistant tuberculosis: the same disease? Clin Infect Dis. 2012;54:1379-80. https://doi.org/10.1093/ cid/cis128 PMid:22492321.

6. Udwadia ZF. MDR, XDR, TDR tuberculosis: ominous progression. Thorax. 2012;67(4):286-88. https://doi.org/10.1136/thoraxjnl-2012-201663 PMid:22427352

7. Miotto P, Piana F, Cirillo DM, Migliori GB. Genotype MTBDR plus: a further step toward rapid identification of drug-resistant Mycobacterium tuberculosis. J Clin Microbiol. 2008;46(1):393-94. https://doi.org/10.1128/JCM.01066-07 PMid:17977988 PMCid:PMC2224251.

8. Zhang D, Lu Y, Liu K, Liu B, Wang J, Zhang G, et al. Identification of less lipophilic riminophenazine derivatives for the treatment of drug-resistant tuberculosis. J Med Chem. 2012;55(19):8409-17. https://doi.org/10.1021/ jm300828h PMid:22931472.

9. Kouidmi I, Levesque RC, Paradis-Bleau C. The biology of Mur ligases as an antibacterial target. Mol Microbiol. 2014;94(2):242-53. https://doi.org/10.1111/ mmi.12758 PMid:25130693.

10. Moraes GL, Gomes GC, Monteiro de Sousa PR, Alves CN, Govender T, Kruger HG, et al. Structural and functional features of enzymes of Mycobacterium tuberculosis peptidoglycanbio synthesis as targets for drug development. Tuberculosis. 2015;95:95-111. https://doi.org/10.1016/j. tube.2015.01.006 PMid:25701501 PMCid:PMC4659487.

11. Mdluli K, Spigelman M. Novel targets for tuberculosis drug discovery. Curr Opin Pharmacol. 2006;6(5):459-67. https://doi.org/10.1016/j. coph.2006.06.004 PMid:16904376.

12. Feltcher ME, Sullivan JT, Braunstein M. Protein export systems of Mycobacterium tuberculosis: novel targets for drug development? Future Microbiol. 2010;5(10):1581-97. https://doi.org/10.2217/fmb.10.112 PMid:21073315 PMCid:PMC3034451.

13. Khokhar M, Kaur N, Jain V, Sandhir R, Gautam A, Bharatam PV, Tewari R. Comparative modeling of pivotal enzymes, MurA and MurZ, of Enterococcus faecalis and identification of potential inhibitors by computational methods. Med Chem Res. 2014;23(4):1819-28. https://doi.org/10.1007/s00044-0130785-z.

14. Shanmugam A, Natarajan J. Homology modeling and docking analyses of M. leprae Mur ligases reveals the common binding residues for structure based drug designing to eradicate leprosy. J Mol Model. 2012;18(6):2659-72. https://doi.org/10.1007/s00894-011-1285-z PMid:22102165.

15. Swain SS, Padhy RN, Singh PK. Anticancer compounds from cyanobacterium Lyngbya species: a review. Antonie van Leeuwenh. 2015;108(2):223-65. https://doi.org/10.1007/s10482-015-0487-2 PMid:26026796.

16. Raveh A, Carmeli S. Antimicrobial ambiguines from the cyanobacterium Fischerella sp. collected in Israel. J Nat Prod. 2007;70(2):196-201. https:// doi.org/10.1021/np060495r PMid:17315959.
17. Sturdy M, Krunic A, Cho S, Franzblau S, Orjala J. Eucapsitrione, an antiMycobacterium tuberculosis anthraquinone derivative from the cultured freshwater cyanobacterium Eucapsis sp. J Nat Prod. 2010;73(8):1441-43. https://doi.org/10.1021/np100299v PMid:20795743 PMCid:PMC2972581.

18. Montasera R, Paulb VJ, Luescha H, Pitipeptolides C-F, antimycobacterial cyclodepsi-peptides from the marine cyanobacterium Lyngbya majuscula from Guam. Phytochemistry. 2011;72:2068-74. https://doi.org/10.1016/j. phytochem.2011.07.014 PMid:21843895 PMCid:PMC3176919.

19. Sali A, Blundell TL. Comparative protein modeling by satisfaction of spatial restraints. J MolBiol. 1993;234(3):779-815. https://doi.org/10.1006/ jmbi.1993.1626 PMid:8254673.

20. Swain SS, Sahu MC, Padhy RN. In silico attempt for adduct agent(s) against malaria: Combination of chloroquine with alkaloids of Adhatoda vasica. Comput Meth Program Biomed. 2015;122(1):16-25. https://doi.org/10.1016/j. cmpb.2015.06.005 PMid:26142781.

21. Schneidman-Duhovny D, Inbar $Y$, Nussinov R, Wolfson HJ. PatchDock and SymmDock: servers for rigid and symmetric docking. Nucl Acid Res. 2005;33:W363-7. https://doi.org/10.1093/nar/gki481 PMid:15980490 PMCid:PMC1160241.

22. Mo S, Krunic A, Chlipala G, Orjala J. Antimicrobial ambiguine isonitriles from the cyanobacterium Fischerella ambigua. J Nat Prod. 2009;72(5):894-99. https://doi.org/10.1021/np800751j PMid:19371071 PMCid:PMC2765494.

23. Moore ER, Yang GXQ, Patterson MLG. Fontonamide and anhydrohapaloxindole $A$, two new alkaloids from the blue-green alga Hapalosiphon fontinalis. J Org Chem. 1987;52(17):3773-77. https://doi. org/10.1021/jo00226a009.

24. Luesch H, Pangilinan R, Yoshida WY, Moore RE, Paul VJ. Pitipeptolides A and $B$, new cyclodepsipeptides from the marine cyanobacterium Lyngbya majuscula. J Nat Prod. 2001;64(3):304-7. https://doi.org/10.1021/np000456u PMid:11277744.

25. Jaki B, Orjala J, Sticher O. A novel extracellular diterpenoid with antibacterial activity from the cyanobacterium Nostoc commune. J Nat Prod. 1999;62(3):502-03. https://doi.org/10.1021/np980444x PMid:10096870.

26. Singh IP, Milligan KE, Gerwick WH. Tanikolide, a toxic and antifungal lactone from the marine cyanobacterium Lyngbya majuscula. J Nat Prod. 1999;62(9):1333-35. https://doi.org/10.1021/np990162c PMid:10514329.

27. Volk RB, Furkert FH. Antialgal, antibacterial and antifungal activity of two metabolites produced and excreted by cyanobacteria during growth. Microbiol Res. 2006;161(2):180-86. https://doi.org/10.1016/j.micres.2005.08.005 PMid:16427523.

28. Costa M, Costa-Rodrigues J, Fernandes MH, Barros P, Vasconcelos V, Martins R. Marine cyanobacteria compounds with anticancer properties: a review on the implication of apoptosis. Mar Drug. 2012;10:2181-07. https:// doi.org/10.3390/md10102181 PMid:23170077 PMCid:PMC3497016.

29. Menon MM, Bhide SV. Perinatal carcinogenicity of isoniazid (INH) in Swiss mice. J Cancer Res Clin Oncol. 1983;105(3):258-61. https://doi.org/10.1007/ BF00395754.

30. Drwal MN, Banerjee P, Dunkel M, Wettig MR, Preissner R. ProTox: a web server for the in silico prediction of rodent oral toxicity. Nucleic Acid Res. 2014;42(W1):W53-58. https://doi.org/10.1093/nar/gku401 PMid:24838562 PMCid:PMC4086068. 


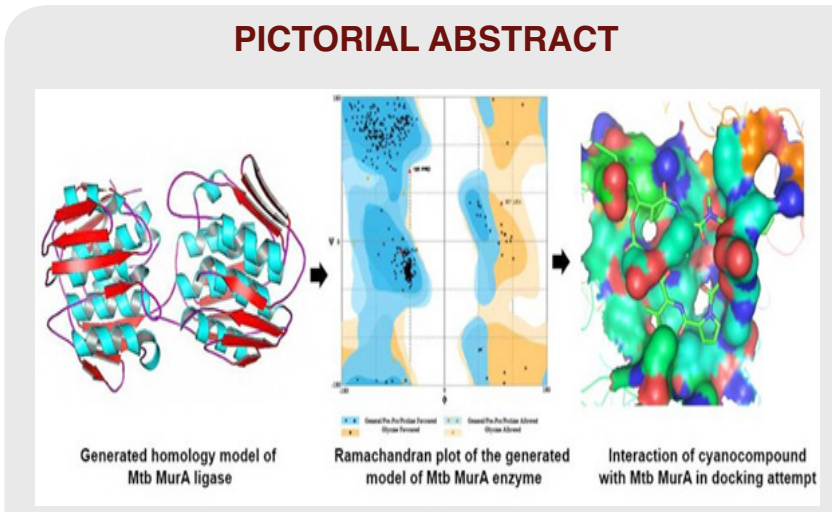

About Authors

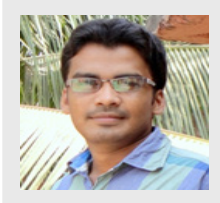

Shasank S. Swain, M.Sc: In Bioinformatics, now working as a $\mathrm{PhD}$ scholar in Biotechnology, IMS \& Sum Hospital, Siksha ' $O$ ' Anusandhan University, Bhubaneswar, Odisha. He has published more than 10 research papers in drug targeting using tool of Bioinformatics and medicinal chemistry.

\section{SUMMARY}

- Mycobacterium tuberculosis causes staggering infections worldwide; particularly its recently drug resistant strains are intractable. Locating or developing a newer controlling antimycobacterials is call of the day.

- The MurA ligase of cell-wall peptidoglycan pathway is the suitable target often used for drug development, and a homology model of MurA enzyme of $M$. tuberculosis was generated and validated by a Ramachandran plot.

- Molecular docking studies with 13 cyanocompounds, along with 4 first-line anti-tuberculosis drugs, isoniazid, pyrazinamide, ethambutol and rifampicin were done for locating effective antimycobacterials.

- Toxicity study is an essential corollary, before the pre-clinical stage of a recommended chemical as a future, which is predicted using tools, ProTox and LAZAR, computationally; both cyano-compounds, pitipeptolides $\mathrm{F}$ and pitipeptolides $\mathrm{D}$ could be taken as suitable as prospective antimycobacterial agents.

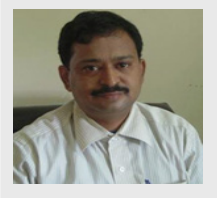

Sudhir K. Paidesetty, M. Pharm., Ph.D:, Is working as Associate Professor, Faculty of Pharmacy, School of Pharmaceutical Sciences, Siksha 'O' Anusandhan University, Bhubaneswar, Odisha. Research interests: Synthesis and biological evaluation of novel chemicals and conjugates. He is a life member of Association of Pharmaceutical Teachers of India.

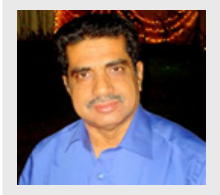

Rabindra N. Padhy, Ph.D., MNAMS: Now is working as Research Professor, IMS \& Sum Hospital, Siksha ' $O$ ' Anusandhan University, Bhubaneswar, Odisha. Research Areas: Microbiology, Medicinal plants, Phyto-chemistry, Environmental sciences, genetics; he was awarded, CSIR Emeritus Scientist, Samanta Chandra Shekhar Award, Outstanding young person. He has outstanding contributions in agricultural and medical sciences.

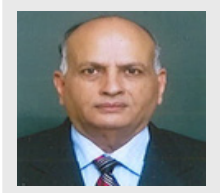

Pawan K. Singh, Ph.D., FNAAS, FNA: Research Areas: Virology, algal and Azolla biotechnology, genetics. Now working as an INSA Senior Scientist; he was awarded with National Fellow Award, Hari Om Ashram Trust Award, INSA Senior Scientist, CSIR Emeritus Scientist. He had held several positions, previously, Head, Soil Science and Microbiology Division, Joint Director and subsequently, Director at CRRI, Cuttack; Project Director, NCCUBGA; Joint Director and Director, IARI, New Delhi; and Vice-Chancellor, C.S. Azad University of Agriculture and Technology, Kanpur. Email: pksalgae@ yahoo.co.in.

Cite this article: Swain SS, Paidesetty SK, Padhy RN, Singh PK. Computational Approach for Locating Effective Cyanobacterial Compounds against Mycobacterium Tuberculosis. Indian J of Pharmaceutical Education and Research. 2017;51(2):302-11. 